\title{
Konservasi Coelogyne pandurata Lindh. di Kalimantan Tengah: karakter morfologi, propagasi in vitro, dan pelestarian berbasis komunitas lokal
}

\author{
T. S. Wahyudiningsih ${ }^{1 *}$, Y. Jagau ${ }^{2}$, N. Ravenska ${ }^{3}$ \\ 1 Program Studi Agroteknologi, Fakultas Pertanian, Universitas Tidar, Magelang, Indonesia \\ 2Program Studi Budidaya Pertanian, Agroteknologi, Fakultas Pertanian, Universitas Palangka Raya, \\ Palangka Raya, Indonesia \\ ${ }^{3}$ Program Studi Pengelolaan Sumber Daya Alam dan Lingkungan, Pascasarjana, Universitas Palangka Raya, \\ Palangka Raya, Indonesia
}

\begin{abstract}
Abstrak.
Coelogyne pandurata merupakan anggrek endemik, termasuk Appendiks I menurut CITES, dan mempunyai nilai ekonomi tinggi. Kebakaran hutan, konversi lahan, eksploitasi tidak terkendali, periode berbunga sangat pendek, dan sulit disilangkan menjadi faktor penyebab yang membuat populasi $C$. pandurata terancam punah sehingga perlu dilakukan konservasi. Penelitian ini bertujuan mengkaji perbedaan karakter morfologi $C$. pandurata dari Muara Teweh dan Tewah, propagasi secara in vitro, serta pelestarian berbasis komunitas masyarakat lokal. Bunga asal Tewah memiliki ciri seperti warna lidah lebih hitam, bulu halus dan ornamen lebih jelas, panjang dan lebar pada bulbus dan daun asal Tewah lebih besar. Eksplan serbuk biji ditanam pada medium perlakuan: I. MS (kontrol), II. MS $+3 \mathrm{mg} / \mathrm{l}$ BAP (Benzyl Amino Purine), III. $\mathrm{MS}+3 \mathrm{mg} / \mathrm{l} \mathrm{BAP}+$ Pisang, IV. MS + $3 \mathrm{mg} / \mathrm{l} \mathrm{BAP}+$ air kelapa, dan V. MS + $3 \mathrm{mg} / \mathrm{l} \mathrm{BAP} \mathrm{+} \mathrm{tomat.} \mathrm{Pada} 10$ HST (Hari Setelah Tanam) terjadi perubahan warna biji kuning menjadi hijau. Pro-meristem mengalami diferensiasi menjadi kutub calon akar pada suspensor dan kutub calon tunas. Protocorm tumbuh pada $21 \mathrm{HST}$. Seedling tumbuh pada 8 MST (Minggu Setelah Tanam) pada perlakuan I, II, dan IV. Pada perlakuan III seedling dengan tunas $0,5 \mathrm{~cm}$ terlihat pada 9 MST. Pada perlakuan V seedling tumbuh pada 11 MST dengan perawakan sehat dan kuat. Komunitas masyarakat lokal dan hutan adat menjadi prioritas awal pembinaan dan pemberdayaan melalui kegiatan pengenalan anggrek, teknik budi daya, pemahaman konservasi serta penanaman ke habitat, sehingga konservasi in-situ dapat berjalan secara berkesinambungan.
\end{abstract}

\begin{abstract}
.
C. pandurata is an endemic orchid, classified as Appendix I according to CITES, and has high economic value. Forest fires, land conversion, uncontrolled exploitation, very short flowering periods, and difficult cross-breeding are factors that make C. pandurata populations endangered, so conservation needs to be carried out. This study aimed to examine the differences of morphological characters from Muara Teweh and Tewah, in vitro propagation, and preservation based local community. The flower from Tewah had a blacker labellum, fluff and ornament more clearly. Seed were planted in the treatment medium: I. MS (control), II. $M S+3 \mathrm{mg} / \mathrm{l}$ BAP, III. $M S+3 \mathrm{mg} / \mathrm{l}$ BAP + bananas, IV. $M S+$ $3 \mathrm{mg} / \mathrm{l} \mathrm{BAP}+$ coconut water, and $V . M S+3 \mathrm{mg} / \mathrm{l} B A P+$ tomatos. At tenth days after planting, germination occurred in all treatments. The pro-meristem underwent differentiation into pole root and pole buds. The average speed appeared protocorm in twenty first days after planting. Seedling growth began at the eighth weeks after planting of treatment I, II, and IV. The treatment III, seedling grew with $0.5 \mathrm{~cm}$ of shoot in ninth weeks after planting. At the treatment $V$, seedling (healthy, strong, and proportional plants) appeared in eleventh weeks after planting. Local community and customary forests became the initial priority to be fostered and empowered through orchid recognition activities, cultivation techniques, understanding of conservation, and planting into habitats so that the in-situ conservation can be sustainable.
\end{abstract}

Keywords: Coelogyne pandurata, morphological character, protocorm, seedling, local community

Kata kunci: Coelogyne pandurata, karakter morfologi, protocorm, seedling, komunitas lokal

\section{PENDAHULUAN}

Genus Coelogyne terdiri dari 125 spesies terdistribusi mulai dari India dan China hingga Asia Tenggara (Indonesia, Filipina, Kepulauan Pasifik dan Fiji

\footnotetext{
${ }^{*}$ Korespondensi Penulis

Email : tri.s.w.basuki@gmail.com
} 
(Abraham and Vatsala 1981). Genus Coelogyne di Kalimantan Tengah terdapat delapan spesies yaitu Coelogyne pandurata, C. asperata, C. cristata, C. cumingii, C. peltates, C. fuliginosa, C. rhocussenii, dan C. zurowetzii. Anggrek C. pandurata merupakan anggrek epifit dan simpodial pada umumnya tumbuh pada cabang batang pohon. Anggrek tersebut banyak ditemukan di Kalimantan Tengah yaitu di Tewah dan Muara Teweh.

Anggrek C. pandurata termasuk tumbuhan yang dilindungi berdasarkan PP RI No 7 Tahun 1999. Hal ini karena terjadi peningkatan koleksi dari pecinta anggrek yang tidak terkendali, eksploitasi berlebihan, kerusakan habitat akibat reklamasi, pembukaan lahan pertanian, deforestasi, hilangnya pollinator, fragmentasi populasi, genetic drift, tekanan antropogenik dan perdagangan ilegal, sehingga anggrek spesies ini mengalami ancaman punah dari alam liar. Menurut Balasubramanian and Murugesan (2004), konservasi di habitat alami, strategi konservasi yang tepat, dan perencanaan pengembangan konservasi dapat melindungi biodiversitas anggrek di suatu daerah.

Propagasi secara in vitro secara substansial dapat mengurangi tekanan populasi $C$. pandurata di alam. Perkecambahan biji $C$. pandurata secara in vitro menjadi salah satu metode yang sangat umum diterapkan pada anggrek untuk tujuan penelitian dan konservasi. Teknik kultur in vitro tidak hanya untuk propagasi secara cepat dan dalam skala besar tetapi juga untuk konservasi secara ex-situ. Arditti and Ernst (1993) mengemukakan bahwa propagasi anggrek skala besar telah dilakukan pada sejumlah genus anggrek antara lain Cymbidium, Vanda, Phaphiopedilum dan Phalaenopsis dengan menggunakan macam eksplan yang berbeda. Propagasi yang lebih mudah dan praktis berasal dari protocorm yang dapat berproliferasi menjadi seedling (Yam et al.1991; Chen et al. 2000).

Protocorm merupakan struktur unik biji pada anggrek, termasuk juga pada anggrek $C$. pandurata. Protocorm adalah struktur awal yang terbentuk selama perkembangan embrio pada saat biji anggrek berkecambah (Ishii et al. 1998). Biji tersebut tidak mempunyai cadangan makanan untuk berkecambah. Biji $C$. pandurata dapat berkecambah dan tumbuh menjadi tanaman baru di alam apabila bersimbiosis dengan endomikorisa, sehingga hanya beberapa biji mampu berkecambah. Satu buah anggrek dapat berisi 1.500 hingga 3.000.000 biji. Buah anggrek $C$. pandurata mempunyai ukuran yang lebih besar dari buah anggrek lainnya, sehingga mempunyai jumlah biji yang lebih banyak. Proliferasi protocorm dan protocorm-like bodies (PLB) sering kali menjadi satu-satunya cara untuk meningkatkan jumlah anggrek. Upaya untuk meningkatkan dan atau mempercepat proliferasi dilakukan dengan cara menambahkan zat pengatur tumbuh ke dalam medium (Arditti 1977). Vajrabhaya (1997) melaporkan bahwa medium yang mengandung hormon dapat mempercepat peningkatan tetapi juga 
dapat menyebabkan mutasi yang tidak diharapkan. Efek samping mutasi dapat dikurangi dengan pengurangan proporsi penggunaan medium, termasuk saat proliferasi protocorm atau PLB yaitu dengan menggunakan konsentrasi hormon yang rendah ( $\mathrm{Gu}$ et al. 1987) atau medium tanpa penambahan hormon tetapi dengan penambahan bahan organik. Bahan organik tersebut antara lain berupa penambahan bahan aditif kompleks seperti jus pisang (Yam et al. 1991), air kelapa (Yam et al. 1991; Ishii et al. 1998) dan tomat.

Berdasarkan hal tersebut di atas maka perbedaan karakter morfologi dan pelestarian jenis $C$. pandurata asal Muara Teweh dan Tewah tersebut yang berbasis komunitas lokal perlu diteliti. Demikian juga propagasi $C$. pandurata secara in vitro dengan eksplan biji pada medium MS dengan perlakuan zat pengatur tumbuh BAP (Benzyl Amino Purin) dan penambahan bahan organik berupa air kelapa, jus pisang dan tomat. Tujuan penelitian ini adalah:

1. Menerangkan perbedaan karakter morfologi daun dan bunga C. pandurata asal Tewah dan Muara Teweh, Kalimantan Tengah.

2. Menguraikan pertumbuhan dan perkembangan biji C. Pandurata berkecambah hingga hingga menjadi seedling.

3. Menguraikan pelestarian anggrek $C$. pandurata berbasis komunitas masyarakat lokal untuk mendukung keberlanjutan konservasi secara in situ.

\section{METODOLOGI}

\subsection{Lokasi kajian dan waktu penelitian}

Penelitian propagasi secara in vitro dilakukan bulan Januari 2011 sampai Januari 2012. Tempat penelitian di Laboratorium Manajemen Hutan, Fakultas Pertanian Universitas Palangka Raya. Penelitian karakteristik morfologi dan cara pemeliharaan $C$. pandurata asal Tewah dan Muara Teweh, Kalimantan Tengah dilakukan di koleksi anggrek hutan Kalimantan Tengah milik ibu Setya Murniasih di Jalan Temanggung Tilung XIII Palangka Raya pada bulan OktoberNovember 2016.

\subsection{Alat dan bahan}

Alat dan bahan yang digunakan dalam penelitian ini disajikan dalam bentuk tabel pada Tabel 1.

Tabel 1. Alat dan bahan penelitian.

\begin{tabular}{l|l}
\hline Bahan & Alat \\
\hline 1. Tanaman C. pandurata. & 1. Autoklaf \\
2. buah $C$. pandurata berumur 6 bulan & 2. Laminar air flow (LAF)-cabinet \\
setelah penyerbukan & 3. seperangkat alat gelas dan logam \\
& 4. mata pisau steril \\
\hline
\end{tabular}




\begin{tabular}{l|l}
\hline Bahan & Alat \\
\hline 3. medium MS + agar (George and & $5 . \quad$ kompor gas \\
Sherington 1984), HCl, dan KOH & 6. kertas pH \\
4. Benzyl adenin (BA) & 7. kertas saring \\
5. Komponen tambahan: Pisang ambon, & 8. sprayer \\
tomat, dan air kelapa & 9. penggaris \\
6. Desinfektan: alkohol 70\%, aquades & 10. mikroskop stereo dan kamera \\
steril, spiritus & \\
\hline
\end{tabular}

\subsection{Cara kerja}

1. Melakukan pencandraan tanaman C. pandurata asal Muara Teweh dan Tewah. Pencandraan meliputi: morfologi batang, daun, bunga, daun kelopak, daun mahkota, struktur lidah (labelum), lama mekar bunga, musim berbunga dan ekologi.

2. Mencari komunitas masyarakat yang melakukan pelestarian anggrek $C$. pandurata dan melakukan wawancara.

3. Menyiapkan pembuatan medium MS: sterilisasi botol dan alat yang digunakan untuk menanam, pembuatan stok makro, mikro, dan vitamin, penimbangan sukrosa, agar, pemblenderan bahan organik (pisang dan tomat), pencampuran seluruh medium, dan sterilisasi medium.

4. Mensterilkan buah C. pandurata di dalam LAF-cabinet: buah direndam dan digojok dalam larutan deterjen $5 \%$ selama 15 menit, kemudian dibilas dengan aquades steril. Buah tersebut dicelupkan dalam alkohol $70 \%$ selama 30 detik, kemudian eksplan dilewatkan di atas lampu bunsen (3 kali). Eksplan dipindah ke cawan petri, diiris secara membujur. Biji siap ditanam ke dalam botol yang telah berisi medium perlakuan: 1) MS (kontrol), 2) $\mathrm{MS}+3 \mathrm{mg} / \mathrm{l} \mathrm{BAP,} \mathrm{3)} \mathrm{MS}+3 \mathrm{mg} / \mathrm{l} \mathrm{BAP}+$ Pisang, 4) $\mathrm{MS}+3 \mathrm{mg} / \mathrm{l}$ $\mathrm{BAP}+$ air kelapa, dan 5) $\mathrm{MS}+3 \mathrm{mg} / \mathrm{l} \mathrm{BAP}+$ tomat.

5. Mengamati perkecambahan, pembentukan protocorm dan seedling, dilakukan setiap hari dengan menggunakan mikroskop stereo serta dilakukan pemotretan.

\section{HASIL DAN PEMBAHASAN}

\subsection{Karakter morfologi}

Batang semu terletak berdekatan atau berjauhan, daun berjumlah 2 helai, lebar atau bulat panjang. Sistem pembungaan tegak lurus atau bergantungan dengan beberapa atau banyak bunga. Daun kelopak biasanya sangat cekung, daun mahkota bunga lebih sempit dibandingkan daun kelopak. Bibir bunga agak melengkung ke bagian dasar, terdapat tiga cuping, cuping bagian pinggir melebar secara berangsur-angsur dari bagian dasar bibir bunga dan juga tegak lurus pada pinggir kolomnya. 
Karakter kualitatif yang diamati meliputi warna bunga, lama mekar bunga, dan warna labelum. Deskripsi perbedaan karakter morfologi batang, daun, bunga, daun kelopak, daun mahkota, dan struktur lidah anggrek C. pandurata yang berasal dari Tewah dan Muara Teweh Kalimantan Tengah disajikan pada Tabel 2 dan Gambar 1. Persamaan C. pandurata asal Tewah dan Muara Teweh adalah lama bunga mekar yaitu 5-7 hari, musim berbunga tergantung pada kesuburan tanaman, kelembaban, suhu, dan intensitas cahaya yang sesuai. Ekologi yang diperlukan juga sama yaitu tempat yang teduh, berupa dataran rendah serta banyak dijumpai di dekat sungai hutan basah.
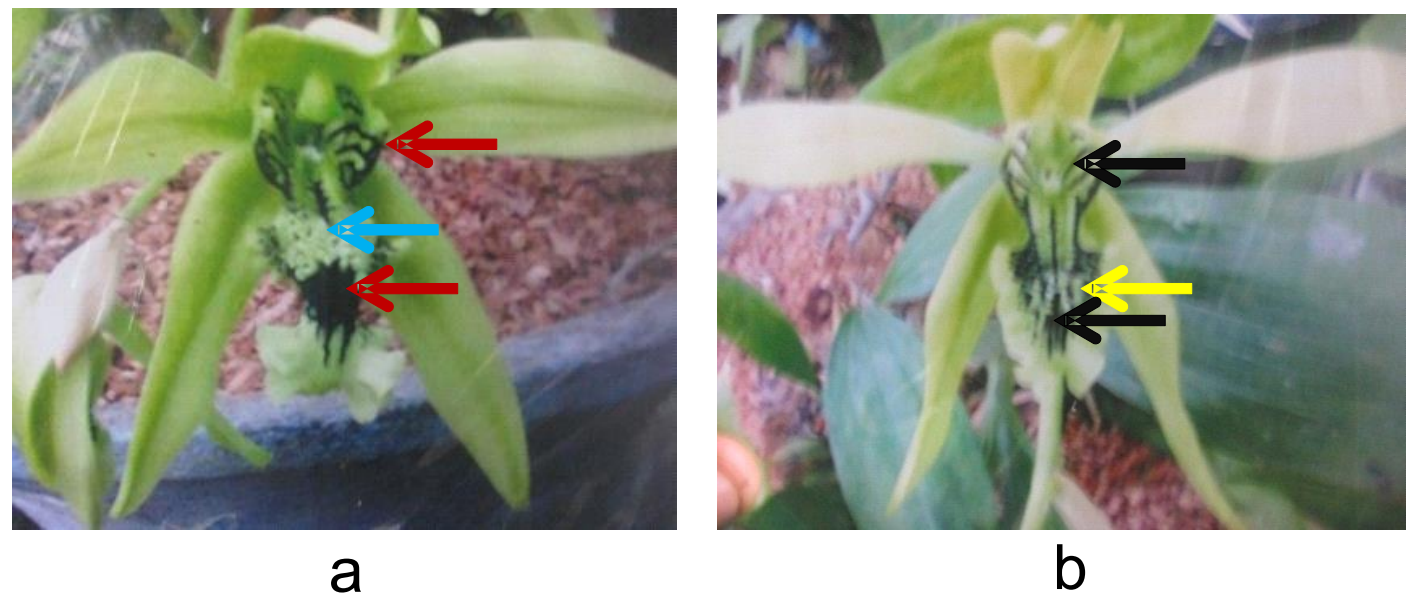

Gambar 1. Morfologi bunga dan tanaman C. pandurata yang berasal dari (a) Tewah dan (b) Muara Teweh, Kalimantan Tengah.

Keterangan: Ornamen dan warna (tanda panah merah) lebih jelas dibanding tanda panah hitam. Labelum mempunyai struktur bulu seperti bludru lebih tebal (tanda panah biru) dibandingkan tanda panah kuning.

Pada penelitian ini konservasi dilakukan bersifat aktif (konservasi ex-situ), yaitu memindahkan tanaman anggrek dari tempat asalnya ke lingkungan yang baru atau tempat pemeliharaan baru, sehingga keanekaragaman plasma nutfah dapat dipertahankan dalam kebun koleksi dan pot-pot pemeliharaan. Konservasi ex-situ dilakukan dengan menanam, memperbanyak, dan memelihara anggrek $C$. pandurata yang berasal dari Tewah dan Muara Teweh di Jalan Temanggung Tilung XIII.

Berdasarkan pengamatan dan pengukuran, maka terdapat perbedaan karakter morfologi organ vegetatif dan organ generatif anggrek $C$. pandurata yang berasal dari Tewah dan Muara Teweh seperti disajikan pada Tabel 2. Salah satu perbedaan karakter morfologi yang menarik dan paling menonjol adalah pada karakter organ generatif yaitu warna, corak, dan ukuran bunga (Gambar 1), sehingga menarik diteliti bagi pemulia anggrek.

Tanaman anggrek mempunyai keistimewaan pada bunganya yang sangat beraneka-ragam dalam hal ukuran, bentuk, warna maupun corak warnanya. 
Demikian juga pada anggrek dari genus Coelogyne maupun dari spesies $C$. pandurata. Hal ini sesuai dengan hasil pengamatan bahwa terdapat perbedaan warna, ukuran, dan corak bunga $C$. pandurata yang berasal dari daerah Tewah dan Muara Teweh. Menurut Strickberger (1985), analisis biokimia terhadap pigmen bunga menunjukkan adanya korelasi antara sifat genetik dan perubahan biokimia. Pewarisan warna dalam hal ini memperlihatkan pengaruh gen dalam pengendalian langkah-langkah dari peristiwa biokimia yang spesifik. Adanya beberapa senyawa yang berperan di dalam pewarnaan bunga anggrek menyebabkan anggota tanaman dari suku Orchidaceae ini mempunyai warna bunga dengan pola pewarnaan yang beraneka ragam dari yang berwarna putih sampai berwarna hampir hitam, ditambah dengan berbagai corak dan kombinasi warnanya. Bunga yang berwarna hijau juga bisa dilihat pada anggrek Cymbidium maupun C. pandurata. Warna hijau pada bunga ini disebabkan oleh adanya klorofil yang juga dapat mengadakan fotosintesis (Arditti 1966).

Tabel 2. Deskripsi morfologi batang, daun, bunga, daun kelopak, daun mahkota, dan struktur lidah (labelum).

\begin{tabular}{|c|c|c|c|}
\hline No & Deskripsi & Asal Tewah & Asal Muara Teweh \\
\hline 1 & Batang & $\begin{array}{l}\text { Berbentuk umbi semu, } \\
\text { panjang: } 1-10 \mathrm{~cm} .\end{array}$ & $\begin{array}{l}\text { Berbentuk umbi semu, panjang: } \\
1-6 \mathrm{~cm} \text {. }\end{array}$ \\
\hline 2 & Pseudobulbus & $\begin{array}{l}\text { Bentuk pipih, panjang: } 2-10 \\
\mathrm{~cm} \text {, dan lebar: } 1,5-8 \mathrm{~cm} .\end{array}$ & $\begin{array}{l}\text { Bentuk pipih, panjang: } 1,5-7 \mathrm{~cm} \text {, } \\
\text { dan lebar: } 1-4 \mathrm{~cm} \text {. }\end{array}$ \\
\hline 3 & Daun & $\begin{array}{l}\text { Bentuk jorong, berlipat-lipat, } \\
\text { panjang: } 20-40 \mathrm{~cm} \text {, dan lebar: } \\
2-8 \mathrm{~cm} \text {. }\end{array}$ & $\begin{array}{l}\text { Bentuk jorong, berlipat-lipat, } \\
\text { panjang: 10-25 cm, dan lebar: } 2- \\
6 \mathrm{~cm} \text {. }\end{array}$ \\
\hline 4 & Bunga & $\begin{array}{l}\text { Tersusun dalam rangkaian } \\
\text { berbentuk tandan, panjang: } \\
15-20 \mathrm{~cm} \text {. Jumlah bunga tiap } \\
\text { tandan: } 7-14 \text { kuntum. }\end{array}$ & $\begin{array}{l}\text { Tersusun dalam rangkaian } \\
\text { berbentuk tandan. Panjang: } 10- \\
15 \mathrm{~cm} \text {. Jumlah bunga tiap } \\
\text { tandan: } 5-12 \text { kuntum. }\end{array}$ \\
\hline 5 & Daun kelopak & $\begin{array}{l}\text { Garis tengah tiap bunga: } 10 \\
\mathrm{~cm} \text {, berbentuk lanset, lancip, } \\
\text { panjang: } 10-15 \mathrm{~cm} \text {, lebar: } 3-5 \\
\mathrm{~cm} \text {, berwarna hijau muda. }\end{array}$ & $\begin{array}{l}\text { Garis tengah tiap bunga: } 8 \mathrm{~cm} \text {, } \\
\text { berbentuk lanset, lancip, } \\
\text { panjang: } 8-13 \mathrm{~cm} \text {, lebar: } 2-4 \mathrm{~cm} \text {, } \\
\text { berwarna hijau muda hingga } \\
\text { hijau kekuningan. }\end{array}$ \\
\hline 6 & Daun mahkota & $\begin{array}{l}\text { Bentuk lanset melancip dan } \\
\text { berwarna hijau muda. }\end{array}$ & $\begin{array}{l}\text { Bentuk lanset melancip dan } \\
\text { berwarna hijau muda hingga } \\
\text { hijau kekuningan. }\end{array}$ \\
\hline 7 & $\begin{array}{l}\text { Struktur lidah } \\
\text { (labelum) }\end{array}$ & $\begin{array}{l}\text { Warna ornamen pada lidah } \\
\text { lebih hitam, bulu-bulu halus } \\
\text { lebih tebal seperti bludru, } \\
\text { garis dan ornamen hitam } \\
\text { berbeda. }\end{array}$ & $\begin{array}{l}\text { Ornamen hitam pada lidah lebih } \\
\text { sedikit dan lebih tipis, bulu-bulu } \\
\text { halus tipis. }\end{array}$ \\
\hline
\end{tabular}




\subsection{Perkecambahan biji C. pandurata hingga menjadi seedling}

Pada Gambar 2a, eksplan berupa buah anggrek berumur 6 bulan setelah penyerbukan, setelah dibelah berisi serbuk biji berwarna kuning keputihan (Gambar 2b). Pada lima hari setelah ditanam serbuk biji yang viable tumbuh menjadi warna hijau di bagian tengah (Gambar 2c). Hal ini karena terjadi perubahan dari plastida menjadi klorofil yang berwarna hijau. Biji yang kosong dan biji yang berisi embrio yang telah mati menunjukkan perubahan warna menjadi cokelat pada lima hari setelah ditanam (Gambar 2d). Pertumbuhan dan perkembangan tiap biji anggrek tersebut tidak terjadi secara bersamaan. Biji yang tidak berisi embrio menunjukkan warna kecokelatan meskipun setelah 10 HST (Gambar 2d).

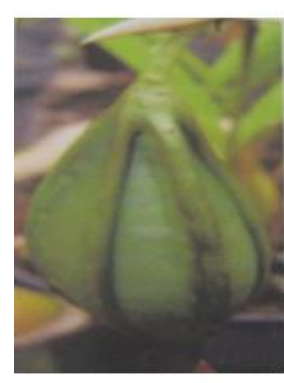

a.

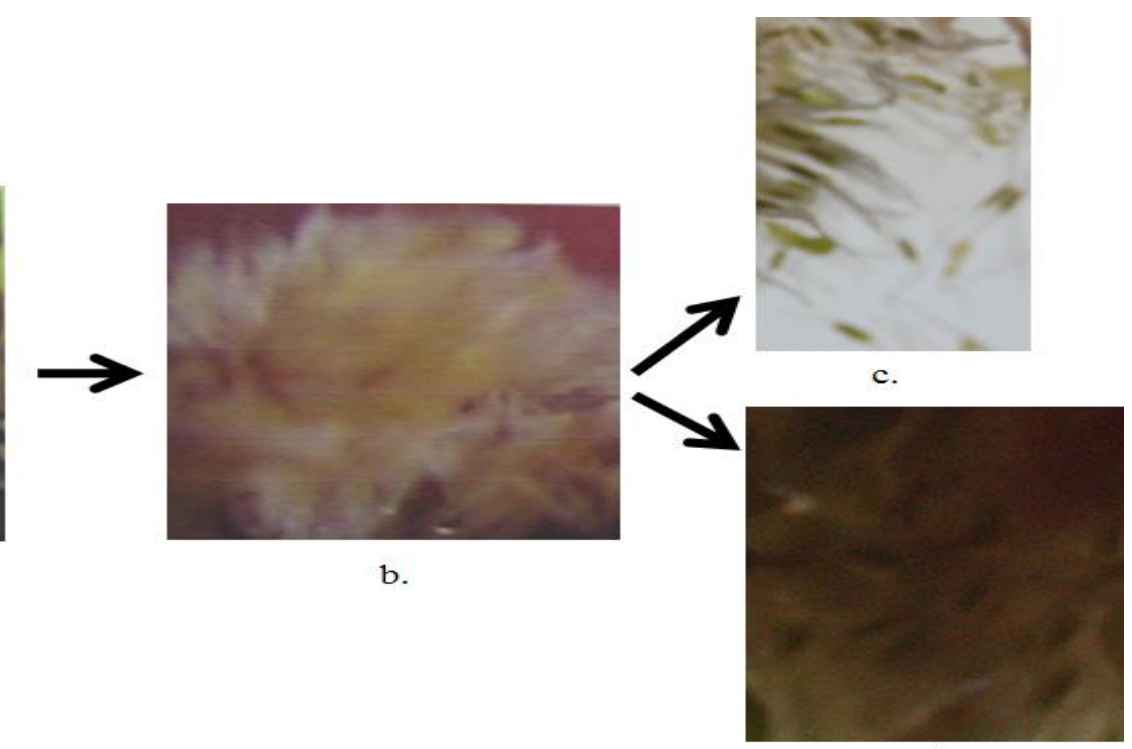

d.

Gambar 2. Eksplan buah (a) yang berisi serbuk biji (b) yang viable tumbuh menunjukkan warna hijau (c), sedang yang biji yang embrio telah mati atau kosong mengalami perubahan menjadi warna cokelat (d).

Pada Gambar 3 mulai 7 HST biji berwarna hijau (a) terlihat bagian tengah berwarna hijau tua (prokambium). Pada 8-10 HST biji tumbuh dan berkembang menjadi lebih panjang dan lebar (b). Prokambium tumbuh memanjang, pada kutub atas terdapat meristem pucuk calon tunas dan kutub bawah terdapat meristem pucuk calon akar. Protocorm mulai terbentuk pada 15 HST (c), suspensor semakin memanjang. Pada 25 HST struktur globuler semakin memanjang (d) diikuti pertumbuhan dan perkembangan tunas dan akar mulai $50 \operatorname{HST}(\mathrm{e})$. 


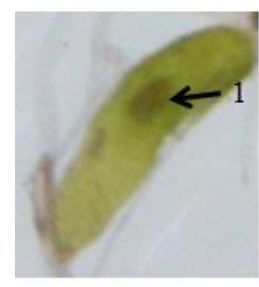

a.

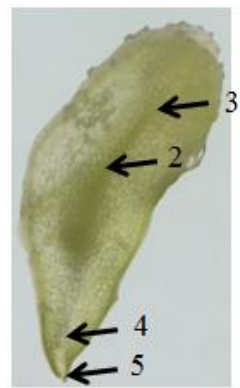

b.

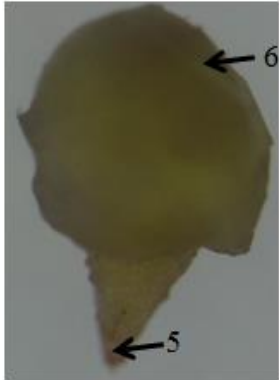

c.

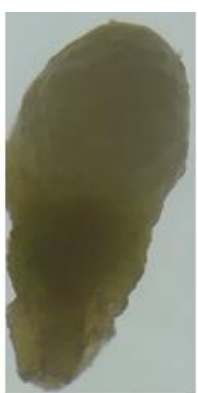

d.

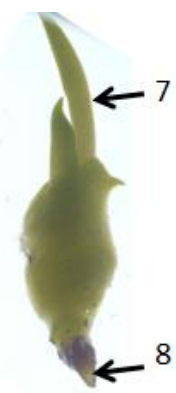

e.

Gambar 3. Pertumbuhan biji anggrek C. pandurata dilihat di bawah mikroskop stereo. Keterangan: a. Pertumbuhan biji umur 7 HST, b. Pertumbuhan biji umur 10 HST, c. Protocorm pada 15 HST, d. Protocorm pada 25 HST, e. Pertumbuhan tunas dan akar pada 50 HST.

1) Pro-meristem, 2) Pro-kambium, 3) Meristem pucuk, 4) Meristem ujung calon akar, 5) Suspensor, 6) Protocorm bentuk globuler, 7) Daun, dan 8) Akar.

\subsection{Medium untuk pertumbuhan protocorm dan seedling C. Pandurata}

Perlakuan yang digunakan dalam penelitian ini ada lima yaitu medium MS (Kontrol/Perlakuan I), MS + 3 mg/l BAP (Perlakuan II), MS + 3 mg/l BAP + jus pisang (Perlakuan III), MS + $3 \mathrm{mg} / \mathrm{l} \mathrm{BAP} \mathrm{+} \mathrm{air} \mathrm{kelapa} \mathrm{(perlakuan} \mathrm{IV),} \mathrm{dan} \mathrm{MS} \mathrm{+} 3$ mg/l BAP + jus tomat (Perlakuan V). Kelima perlakuan tersebut dapat mengecambahkan biji anggrek $C$. pandurata. Pertumbuhan dan perkembangan biji anggrek C. pandurata pada kelima perlakuan disajikan pada Gambar 4.

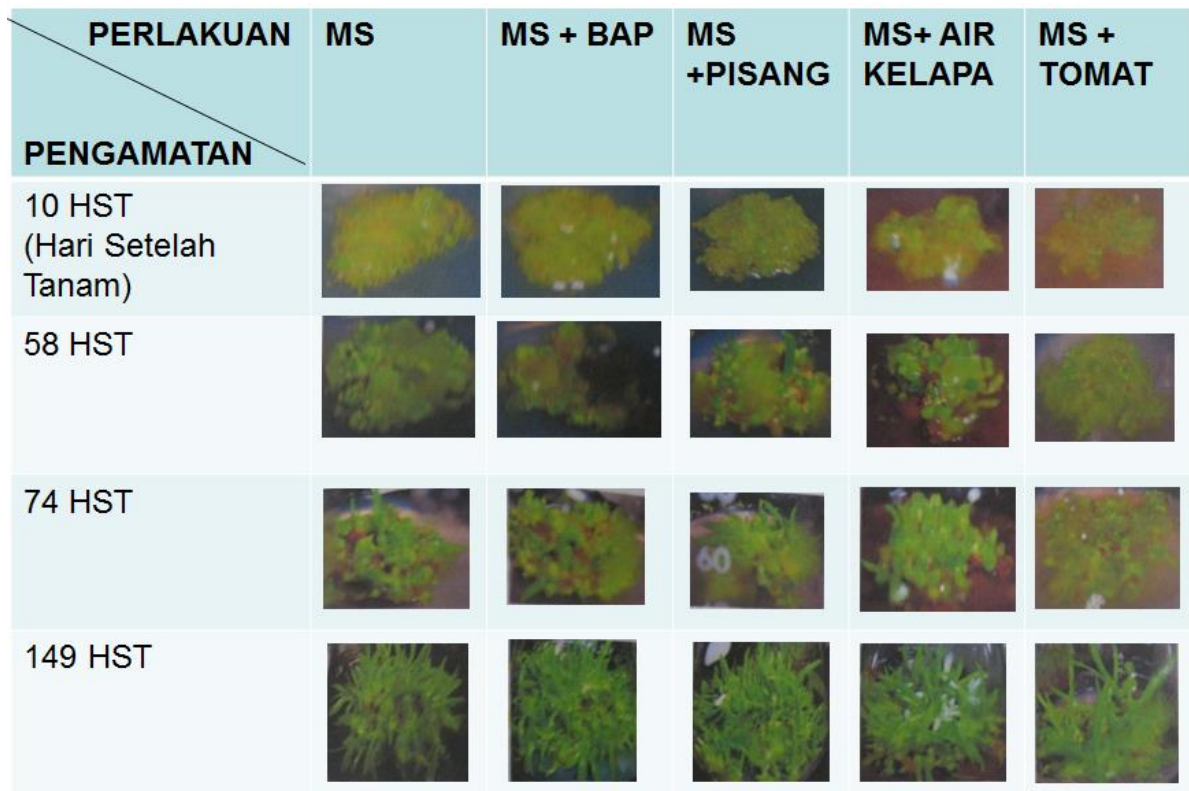

Gambar 4. Pertumbuhan dan perkembangan biji anggrek C. pandurata pada 4 waktu pengamatan (HST) dari lima perlakuan medium yang berbeda. 
Pada 10 HST perkecambahan, semua perlakuan terlihat perubahan warna biji yang sebelumnya kuning menjadi tampak hijau di permukaan medium, selanjutnya protocorm tersebut mengalami pertumbuhan dan perkembangan lebih lanjut. Rerata kecepatan muncul protocorm pada 21 HST (Hari Setelah Tanam). Pada 58 HST calon tunas, akar, dan daun mengalami pertumbuhan dan perkembangan membentuk seedling. Rerata kecepatan muncul seedling pada semua perlakuan yaitu 91 HST (13 MST).

Rerata jumlah tunas pada 7 MST (Minggu Setelah Tanam) dan jumlah akar pada 15 (MST) dari lima perlakuan medium disajikan pada Tabel 3. Pada medium MS tanpa penambahan BAP dan bahan organik, rerata jumlah tunas paling tinggi, namun tunas tersebut berukuran lebih kecil dibandingkan tunas pada perlakuan yang lain. Peringkat rerata jumlah tunas dan akar yang kedua menunjukkan seedling dengan perawakan yang sehat dan kuat, yaitu terdapat pada perlakuan penambahan jus tomat. Pada perlakuan penambahan jus pisang menunjukkan rerata jumlah akar tertinggi.

Tabel 3. Rerata jumlah tunas pada 7 MST (Minggu Setelah Tanam) dan jumlah akar pada 15 MST dari lima perlakuan medium.

\begin{tabular}{|c|c|c|}
\hline Perlakuan & $\begin{array}{l}\text { Rerata jumlah tunas } \\
\text { (7 MST) }\end{array}$ & $\begin{array}{l}\text { Rerata jumlah akar } \\
\text { (15 MST) }\end{array}$ \\
\hline MS & 8,75 & 4,00 \\
\hline $\mathrm{MS}+3 \mathrm{mg} / \mathrm{l} \mathrm{BAP}$ & 4,25 & 2,67 \\
\hline $\mathrm{MS}+3 \mathrm{mg} / \mathrm{l} \mathrm{BAP}+$ jus pisang & 3,25 & 16,00 \\
\hline $\mathrm{MS}+3 \mathrm{mg} / \mathrm{l} \mathrm{BAP}+$ air kelapa & 6,50 & 4,00 \\
\hline MS + 3 mg/l BAP + tomat & 7,75 & 9,00 \\
\hline
\end{tabular}

Rerata kecepatan muncul protocorm pada 21 HST atau 3 minggu setelah tanam. Seedling terbentuk mulai 58 HST atau sekitar 8 minggu setelah tanam (MST). Medium MS lebih lengkap komposisi nutrisi untuk perkecambahan dan perkembangan seedling dari eksplan biji anggrek C. pandurata. Pada penelitian ini digunakan penambahan bahan organik berupa jus pisang, air kelapa dan jus tomat untuk mengurangi penggunaan zat pengatur tumbuh sebagai antisipasi efek samping mutasi akibat penggunaan hormon yang berlebihan.

Kecepatan perkecambahan dan terbentuk seedling pada penelitian ini lebih cepat dibanding hasil penelitian Lestari dan Deswiniyanti (2015) yang menyatakan bahwa perkecambahan biji anggrek $C$. pandurata terjadi pada minggu ke 5 dan seedling terbentuk pada minggu ke-16 dengan menggunakan media VW (Vacin dan Went) dan media organik. Media organik tersebut terdiri dari pupuk Growmore 4 gr, 60 gram pisang ambon, 20 gr gula, $150 \mathrm{mg}$ vitamin C, 1 gr arang aktif, air kelapa $150 \mathrm{ml}$, air rebusan tauge $150 \mathrm{ml}$ dan aquades steril hingga 1 liter. 
Sumber eksplan (Ishii et al. 1998), tingkat kemasakan biji (Chen et al. 2000), dan ukuran buah (Park et al. 2002) mempengaruhi keberhasilan pada prosedur kultur menggunakan air kelapa dan arang aktif untuk multiplikasi protocorm Phalaenopsis gigantea yang dilukai dan tidak dilukai (Murdad et al. 2006). Perkecambahan biji pada $C$. nervosa dalam kondisi asimbiotik terjadi pada 44-100 hari (Shibu et al. 2012; Sonia et al. 2012). Perkecambahan biji pada genus Coelogyne dalam kondisi asimbiotik sekitar 14-60 hari (Kathiyar et al. 1987; Ananthan et al. 2003; Basker et al. 2004; Sebastinraj et al. 2006; Nongrum et al. 2007; Naing et al. 2011; Sathiyadash 2014).

Perkecambahan biji anggrek dapat juga dirangsang dengan menggunakan inokulasi fungi sehingga lebih cepat berkecambah dan meningkatkan persentase survival seedling saat aklimatisasi. Hal tersebut telah diteliti pada perkecambahan biji anggrek Grammatophyllum speciosum, terjadi perubahan warna menjadi hijau pada 30 hari setelah medium diinokulasi dengan fungi (Salifah et al. 2011). Perkembangan protocorm pada Coelogyne nervosa tergantung pada keberadaan fungi Epulorhia epidendreae, demikian juga pada Habenaria macroceratitis (Stewart and Kane 2006).

\subsection{Pelestarian anggrek C. pandurata berbasis komunitas masyarakat lokal}

Ekosistem hutan hujan tropis merupakan habitat utama anggrek $C$. pandurata. Labellum bunga anggrek berwarna hitam sehingga menyimpan gen spesifik dan mempunyai keunikan bagi peneliti dan pecinta anggrek. Berdasarkan hasil pengamatan terdapat gradasi warna hitam, corak dan ukuran bunga bervariasi, sehingga perlu dilakukan konservasi supaya plasma nutfah $C$. Pandurata tetap lestari. Minat pecinta anggrek $C$. pandurata semakin besar, sehingga perilaku mengambil langsung anggrek spesies dari habitat dan hutan semakin meningkat di wilayah Palangka Raya, Tewah, Muara Teweh, dan kabupaten lain di Kalimantan Tengah. Transaksi jual beli anggrek spesies yang masih bebas dilakukan serta pengambilan anggrek dengan membawa sebagian pohon yang menjadi inangnya berdampak bukan hanya populasi berkurang tetapi juga mengancam kelestarian hutan.

Pemerintah telah mengatur dan menyatakan bahwa anggrek $C$. pandurata termasuk tumbuhan yang dilindungi berdasarkan PP RI No 7 Tahun 1999. Perdagangan/penjarahan tumbuhan anggrek $C$. pandurata telah melanggar Undang-Undang No 5 tahun 1990 tentang Konservasi Sumberdaya Alam Hayati dan Ekosistemnya, Pasal 21 ayat (1) huruf (a dan b) dinyatakan mengambil, menebang, memiliki, merusak, memusnahkan, memelihara, mengangkut, dan memperniagakan tumbuhan yang dilindungi atau bagian-bagiannya dalam keadaan hidup atau mati. Upaya perlindungan terhadap lingkungan hidup 
dilakukan melalui tindakan preventif berupa penerapan suatu syarat-syarat yang harus dipenuhi sebelum usaha atau kegiatan dilakukan. Pelanggaran terhadap ketentuan yang ada dilakukan tindakan represif berupa sanksi administrasi, perdata atau pidana. Upaya preventif melalui penyuluhan dan sosialisasi kepada masyarakat sekitar hutan serta penjagaan posko. Upaya represif dengan penangkapan dan penyitaan terhadap masyarakat yang memiliki dan menyimpan tumbuhan yang dilindungi. Peraturan tersebut menunjukkan hasil yang positif. Namun program pemanfaatan mengalami hambatan terutama disebabkan oleh masih terbatasnya peraturan perundangundangan, kesadaran dan persepsi masyarakat terhadap bidang konservasi, pengetahuan ekologi tumbuhan liar dan tenaga terampil dibidang pengelolaan tumbuhan liar (Sumual 2011).

Faktor-faktor yang menyebabkan anggrek $C$. pandurata semakin langka antara lain faktor ekonomi (keuntungan yang berlipat ganda bila diperdagangkan), kurangnya pemahaman masyarakat tentang peraturan atau undang-undang yang berlaku, minimnya penyuluhan dari BKSDA dan lembaga terkait tentang tumbuhan yang dilindungi, kurangnya pengamanan BKSDA dalam penjagaan kawasan konservasi yang sangat luas, ringan hukuman bagi penjarah serta kurangnya kesadaran masyarakat akan pentingnya plasma nutfah anggrek C. pandurata (Sumual 2011). Kepunahan plasma nutfah anggrek menjadi tanggung jawab semua masyarakat sebagai warga negara dan pecinta anggrek. Budi daya, memelihara dan mengembangbiakkan anggrek menjadi salah satu langkah konservasi.

Konservasi ex-situ oleh pengepul dan upaya budi daya konvensional anggrek spesies di Palangka Raya telah dilakukan pada tiga tempat yaitu di jalan Temanggung Tilung XIII, beberapa pedagang tanaman hias di Jalan Lambung Mangkurat dan jalan Yos Sudarso. Selain itu, budi daya dan pemeliharaan anggrek spesies juga dilakukan di lingkungan kantor Gubernur Kalimantan Tengah dan para pecinta anggrek dari bermacam-macam profesi. Tindakan konservasi ex-situ tersebut belum efektif bila tidak disertai langkah konservasi secara in-situ.

Eksploitasi anggrek spesies oleh masyarakat tanpa memperhatikan kelestarian hutan menjadi masalah, sehingga perlu dilakukan tindakan konservasi. Konservasi anggrek C. pandurata secara in-situ hanya dapat berhasil dan berkesinambungan dengan melibatkan masyarakat di sekitar wilayah hutan, misalnya di kawasan hutan sekitar daerah aliran sungai Kahayan dan Hutan Pendidikan Universitas Palangka Raya. Peran eksploitor, konservator, dan rehabilitator melalui pemberdayaan masyarakat lokal lebih efektif dibanding konsep konservasi secara terpusat. Semakin banyak gerakan komunitas lokal 
pelestari anggrek spesies yang potensial di tingkat bawah maka akan mempermudah jalannya upaya konservasi.

Upaya adat dalam melestarikan C. pandurata telah dilakukan oleh suku dayak Benuah di Kalimantan Timur yang sangat menghormati keberadaan anggrek hitam. Suku tersebut berkeyakinan bahwa anggrek hitam mempunyai daya mistis sehingga tidak diperbolehkan mengambil dan mencuri dari kawasan hutan (Sumual 2011). Komunitas-komunitas potensial di kawasan habitat anggrek alam atau yang berbatasan dengan habitat anggrek harus menjadi prioritas awal untuk dibina dan diberdayakan. Hal ini karena komunitas tersebut yang berhubungan langsung dengan kelestarian habitat anggrek. Masyarakat lokal di sekitar hutan harus berpikir lebih jauh supaya potensi wilayahnya tidak langsung dibawa keluar dari wilayahnya. Masyarakat lokal yang menjual anggrek alam dengan harga tinggi bukan langkah efektif mengatasi kelestarian anggrek (Syahril 2013).

Pembinaan dan pemberdayaan melalui kegiatan pengenalan spesies anggrek, teknik budi daya, pemahaman konservasi, penanaman anggrek hitam ke habitatnya dan ilmu-ilmu yang mendukung perlu dilakukan. Sasaran ditujukan untuk masyarakat lokal di daerah sekitar habitat anggrek, pengepul dan penjual serta masyarakat pecinta anggrek spesies. Penguatan kelembagaan komunitas masyarakat lokal sekitar habitat dan pecinta anggrek spesies perlu didukung oleh institusi, universitas, LSM, dinas terkait dan investor lokal. Komunitas lokal dan komunitas adat yang telah ada didorong untuk mempunyai tanggung jawab moril dalam penjagaan kelestarian anggrek spesies di habitatnya. Rasa memiliki dengan tidak mengeksploitasi perlu dipupuk dan ditingkatkan. Rasa ingin melindungi kekayaan plasma nutfah anggrek sebagai warisan yang berkesinambungan juga perlu dilakukan komunitas masyarakat lokal. Hal ini ditunjukkan dengan membeli anggrek spesies yang telah dibudidayakan dan bukan anggrek spesies yang diambil dari alam. Pelestarian anggrek $C$. pandurata dan anggrek spesies lainnya akan berjalan apabila memberi manfaat yang nyata bagi masyarakat lokal dan masyarakat pecinta anggrek.

\section{KESIMPULAN DAN SARAN}

Morfologi bunga asal Tewah mempunyai lidah lebih hitam, bulu halus dan ornamen pada lidah lebih jelas. Perawakan, panjang dan lebar bulbus serta panjang dan lebar daun yang berasal Tewah juga lebih besar. Pada 10 HST (Hari Setelah Tanam) perkecambahan di semua perlakuan terjadi perubahan warna serbuk biji kuning menjadi hijau. Pro-meristem mengalami diferensiasi menjadi dua kutub yaitu kutub calon akar pada daerah suspensor dan kutub calon tunas. Rerata kecepatan muncul protocorm pada 21 HST. 
Pertumbuhan seedling mulai terlihat pada umur 8 MST (Minggu Setelah Tanam) pada perlakuan I, II, dan IV. Pada perlakuan III seedling tumbuh dengan tunas berukuran 0,5 cm terjadi pada 9 MST. Pada perlakuan V meskipun seedling muncul pada $11 \mathrm{MST}$, namun perawakan sehat, kuat dan proporsional antara tunas dan akar. Komponen kimia yang terkandung dalam tomat dan BAP berperan mempercepat pembelahan sel pada meristem akar dan tunas.

Komunitas masyarakat lokal dan hutan adat menjadi prioritas awal pembinaan dan pemberdayaan melalui kegiatan pengenalan anggrek, teknik budi daya, pemahaman konservasi serta penanaman ke habitat, sehingga plasma nutfah dan konservasi in-situ lestari berkesinambungan.

\section{DAFTAR PUSTAKA}

Abraham A and Vatsala P. 1981. Introduction to orchids. Tropical Botanic Garden and Research Institute. Trivandrum.

Ananthan R, Narmatha BV, Jeyakodi L and Jayakalaimathy K. 2003. Mass propagation of Coelogyne mossiae, an endemic orchid. In: Madhystha MN (Ed.). Prospectus and problems of environment across the millennium. Daya Publishing House. New Delhi. p 267-274.

Arditti J. 1966. Orchids. Scientific American 214:70-78.

Arditti J. 1977. Clonal propagation of orchids by means of tissue culture, a manual. In: Orchid Biology Reviews and Prospectives. Cornell University Press. New York. p 203-293.

Arditti J and Ernst R. 1993. Micropropagation of orchids. John Wiley \& Sons, Inc. New York. p. 682.

Balasubramanian V and Murugesan M. 2004. A note on the commercially exploited medicinal plants of the Velliangiri Hills, Coimbatore District, Tamil Nadu. Ancient Science of Life Journal 23:9-12.

Basker C, Deepa MA and Narmatha BV. 2004. Asymbiotic seed germination and seedling development of Coelogyne stricta-an endemic orchid. Journal of Non Timber Forest Products 11:120-124.

Chen YC, Chang C and Chang WC. 2000. A reliable protocol for plant regeneration from callus culture of Phalaenopsis. In Vitro Cell. Dev. Biol. Plant 36:420423.

George EF and Sherrington PD. 1984. Plant propagation by tissue culture: handbook and directory of commercial laboratories. Exegetics Ltd. Eversley.

$\mathrm{Gu}$ Z, Pauline, CH, Michael, MN, Arditti J and Leslie. 1987. The effect of benzyladenine 2,4-dichlorophenoxyacetic acid, and indolacetic acid on shoot tip culture of Cymbidium. Lindleyana 2(2):88-90. 
Ishii Y, Takamura T, Goi M and Tanaka M. 1998. Callus induction and somatic embryogenesis of Phalaenopsis. Plant Cell Rep 17:446-450.

Kathiyar RS, Sharma GD and Mishra RR. 1987. Asymbiotic seed germination and seedling development in Coelogyne punctulata and Aerides multiflorum. Indian Forester 113:574-577.

Lestari NKD dan Deswiniyanti NW. 2015. Perbanyakan anggrek hitam (Coeloegyne pandurata) dengan media organik dan Vacin dan Went secara in vitro. Jurnal Virgin 1:30-39.

Murdad R, Hwa KS, Seng CK, Latip MA, Aziz ZA and Ripin R. 2006. High frequency multiplication of Phalaenopsis gigantea using trimmed bases protocorms technique. Scientia Horticulturae 111:73-79.

Naing AH, Chung JD, Park IS and Lim KB. 2011. Efficient plant regeneration of endangered medicinal orchid, Coelogyne cristata using protocorm like bodies. Acta Physiologia Plantarum 33:659-666.

Nongrum I, Kumaria S and Tandon P. 2007. Influence of in vitro media on asymbiotic germination, plantlet development and ex vitro establishment of Coelogyne ovalis Lindl. and Coelogyne nitida (Wall. ex Don.) Lindl [Proceeding]. Proceedings of Indian National Science Academy 73:205207.

Park SY, Yeung EC, Chakrabarty D and Paek KY. 2002. An efficient direct induction of protocorm-like bodies from leaf subepidermal cells of Doritaenopsis hybrid using thin-section culture. Plant Cell Rep 21:46-51.

PP RI (Peraturan Pemerintah Republik Indonesia) Nomor 7 Tahun 1999 tentang pengawetan jenis tumbuhan dan satwa.

Salifah HAB, Muskhazli M, Rusea G and Nithiyaa P. 2011. Variation in mycorrhizal specificity for in vitro symbiotic seed germination of Grammatophyllum speciosum Blume. Sains Malaysiana 40:451-455

Sathiyadash K, Muthukumar T, Murugan SB, Sathishkumar R and Pandhey RR. 2014. In vitro symbiotic seed germination of South Indian endemic orchid Coelogyne nervosa. Mycoscience 55:183-189.

Sebastinraj J, Brito JJ, Robinson PJ, Kumar VD and Kumar SS. 2006. In vitro seed germination and plantlet generation of Coelogyne mossiae Rolfe. Biological Research 5:79-84

Shibu S, Devi C, Wesley S and Moin S. 2012. Ex situ conservation of endemic orchids of Western Ghats, Tamil Nadu, India via asymbiotic seed germination. Advanced Applied Science Research 3:3339-3343.

Sonia A, Augustine J and Thomas DT. 2012. Asymbiotic seed germination and in vitro conservation of Coelogyne nervosa A. Rich. an endemic orchid to Western Ghats. Physiology and Molecular Biology of Plants 18:245-251. 
Stewart SL and Kane ME. 2006. Asymbiotic germination and in vitro seedling development of Habenaria macroceratitis (Orchidaceae), a rare Florida terrestrial orchid. Plant Cell Tissue and Organ Culture 86:147-158.

Strickberger MW. 1985. Genetics, third edition. Macmillan Publishing Company. New York.

Sumual OR. 2011. Upaya Perlindungan Anggrek Hitam (Coelogyne pandurata Lind) di Cagar Alam Kersik Luway ditinjau dari UU No. 5 Tahun 1990 tentang Konservasi Sumberdaya alam Hayati dan Ekosistemnya [Skripsi]. Fakultas Hukum, Universitas Mulawarman. Samarinda.

Syahril R. 2013. Melestarikan anggrek langka dari puspa pesona sampai anggrek tebu [Skripsi]. Fakultas Pertanian, Universitas Hasanudin. Makassar.

Undang-Undang Nomor 5 tahun 1990 tentang konservasi sumberdaya alam hayati dan ekosistemnya.

Vajrabhaya T. 1997. In: Arditti J. (Ed.). Orchid Biology Part I. Cornell University Press. New York. pp 179-201.

Yam TW, Ernst R, Arditti J and Ichihashi S. 1991. The effects of complex additives and 4-dimethylamino pyridine on the proliferation of Phalaenopsis protocorms. Lindleyana 6(1):24-26. 